\title{
Is the current law on Conspiracy to commit Murder effective and fair?
}

Chloe Collins, Chelsie Rapley, Brian Chia, Luke Smith, Ben Middlemass

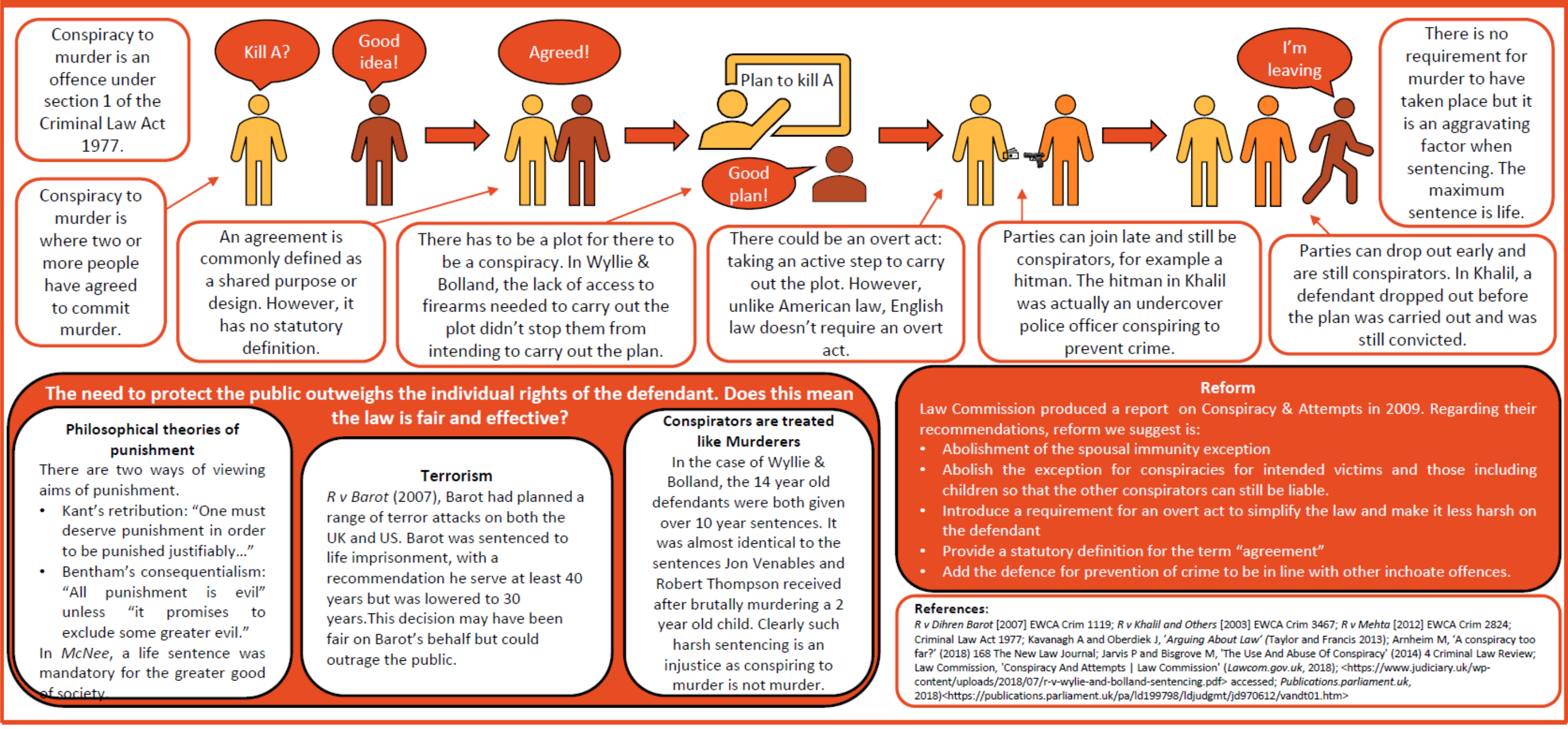




\section{Is the current law on Conspiracy to commit Murder effective and fair?}

Brian Chia

Chelsie Rapley

Chloe Collins

Luke Smith

Ben Middlemass 


\section{Volume 1 Issue 1 Student Journal of Professional Practice and Academic Research}

\section{Introduction}

"Conspirators be they that...bind themselves by Oath...or other Alliance, that every of them shall aid and support the Enterprise of each other falsely and maliciously to indite."1 Established in the Third Ordinance of Conspirators in 1304; the first definition of conspiracy was to prevent and punish those who would plan to use children to present their false accusations in court on their behalf (as children could not be criminally liable). The aim of the law on conspiracy, although widening the scope, has been clear from the thirteenth century: to prevent and punish the planning of a criminal offence. However, since expanding, the law on conspiracy has been criticised especially in regard to sentencing as "unduly harsh." 2 This is the result of numerous problems with the current law on conspiracy to murder, which is in urgent need of reform. "On the $10^{\text {th }}$ of October 2007, the law commission proposed many recommendations on reforms of statutory conspiracy." 3 The focus of this legal research is to explore the current state of law regarding conspiracy to murder and the legislation, case law, scholarly and media articles discussed in this report will evaluate the effectiveness and fairness of the law on conspiracy to murder. Thus, the question to sum up our legal research "Is the current law on conspiracy to commit murder effective and fair?

\section{Current law on Conspiracy to Murder}

"Conspiracy" derives from the Latin words "con" and "spirare" meaning "to breathe together"4 and can be defined as an act where two or more people have agreed to commit a crime ${ }^{5}$, but is also defined within the Criminal Law Act $1977 .{ }^{6}$ Murder can be defined as "the unlawful killing of another human being, under the Queen's peace, with malice aforethought.”7 Combining these two offences creates the offence of conspiracy to murder which essentially is an agreement to commit the unlawful killing of another human being. It is an offence for any

\footnotetext{
${ }^{1}$ JF Stephen, A History of the Criminal Law of England, 2 228-229

See also: CR Snyman, 'The History And Rationale Of Criminal Conspiracy' (1984) 17 The Comparative and International Law Journal of Southern Africa.

2 Dr Michael Arnheim, 'A conspiracy too far?’ (2018) 168 The New Law Journal

3 Law Commission, 'Conspiracy And Attempts | Law Commission' (2018)

${ }^{4}$ Paul Jarvis and Michael Bisgrove, 'The Use And Abuse Of Conspiracy' (2014) 4 Criminal Law Review.

${ }^{5}$ Jacqueline Martin and Tony Storey, Unlocking Criminal Law $\left(6^{\text {th }}\right.$ edn Routledge) chapter 6.3

${ }^{6}$ Criminal Law Act 1977, S.1

${ }^{7}$ Sir Edward Coke, Institutes of the Laws of England (1797)
} 


\section{Volume 1 Issue 1 Student Journal of Professional Practice and Academic Research}

party to conspire to murder.8 There are some exceptions as to who can commit conspiracy as a person cannot be convicted if the only other party is an intended victim, spouse, or child under the age of criminal responsibility (10 years old $)^{9}$.

In Khalil ${ }^{10}$ the appellants were charged with conspiring to murder Qayum, the victim. An undercover police officer disguised as "Mick" acted as a hitman, Hussain went to Mick in order to have Qayum murdered for having an affair with his daughter. LJ Tuskey clarified that it is a criminal offence for two or more persons to agree with one another to commit an offence and that the actual conspiracy is the agreement made between those parties. However, the judgement gives no definition of what an "agreement" is. It has been left to courts to define this term. This could be to allow flexibility in the law, however the understood definition is that "agreement" is where "the parties to it have a common unlawful purpose or design."11

Khalil also confirmed; it does not matter where a conspirator's involvement appears on the scale of seriousness or precisely where they became involved, they are still guilty. This is a clear example of how harsh convictions can be in conspiracy cases especially in this case for Nazar, who dropped out before the crime had been carried out, yet still faced conviction. ${ }^{12}$

The sentencing of conspiracy to murder has always carried a maximum sentence of imprisonment for life ${ }^{13}$ and this remains in the new legislation. ${ }^{14}$ However, judges are allowed to decide if life imprisonment is necessary. There is a code of sentencing that judges use and examples of this are $\operatorname{Raw}^{15}$ and Daddow ${ }^{16}$. The court concluded that a sentence of eighteen years for conspiracy to murder is not excessive, since murder was carried out. It is important to note that, murder itself is not a requirement for the offence of conspiracy to murder however is an aggravating factor.

\footnotetext{
${ }^{8}$ Criminal Law Act 1977 S 1(1)

${ }^{9}$ Criminal Law Act 1977 S 2

${ }^{10} R v$ Khalil and Others [2003] EWCA Crim 3467

${ }^{11} R v$ Mehta (Subhash) [2012] EWCA Crim 2824

${ }^{12}$ Khalil (n 10)

${ }^{13}$ Offences Against the Person Act 1861 c 100 (Regnal 24 and 25 Vict) S 4

${ }^{14}$ Criminal Law Act 1977 S 3(2)(a)

${ }^{15} R$ v Raw (1983) 5 Cr App R (S) 229

${ }^{16} R$ v Daddow [1996] 2 Cr App R (S) 10
} 


\section{Volume 1 Issue 1 Student Journal of Professional Practice and Academic Research}

\section{Problems with the Current law:}

\section{Philosophical aspects of Sentencing}

There are two types of criminal law theories on punishment: Immanuel Kant's retribution view and Jeremy Bentham's consequentialism view. From the perspective of Kant, a criminal must deserve punishment; "thus, one must deserve punishment in order to be punished justifiably..." 17 Conversely, the perspective of Bentham, "all punishment is evil” unless "it promises to exclude some greater evil." ${ }^{18}$ A life sentence will deter the criminal to commit the crime again. Therefore, deserving to be punished is "neither necessary nor sufficient for punishment."19 In Kant's view, punishment will still be insisted even though there is no positive outcome but "the importance of desert to the justification of punishment is hard to deny." ${ }^{20}$ In a modern working society, it can seem slightly pointless imprisoning someone. If there is no positive effect on society, or the prisoner then, it would be a waste of financial resources.

In contrast, Bentham acknowledges the fact that punishment must be counter-balanced by some greater social good. ${ }^{21}$ This balance is important to maintain fairness in the criminal law as although society need protecting, criminals still have rights and need to be punished deservingly; not just to keep them away from society. Without a doubt, Parliament should consider these legal theories when reforming the sentencing procedure in criminal offences, especially in offences for conspiring to murder.

$\mathrm{McNee}^{22}$ which posed the question "are discretionary life sentence appropriate" 23 in conspiracy to murder cases? The appellants: McNee, Gunn and Russell were convicted for conspiracy to murder and were "sentenced to life imprisonment, with minimum terms fixed at 25 years, 35

\footnotetext{
17 'IX. CRIMINAL LAW THEORY: PUNISHMENT' Aileen Kavanagh and John Oberdiek, 'Arguing About Law' (Taylor and Francis 2013) 469

${ }^{18}$ Bentham as cited by Aileen Kavanagh and John Oberdiek, Arguing About Law (Taylor and Francis 2013) 469

${ }^{19}$ Kavanagh and Oberdiek, (n 17) 469-470

20 ibid 470

${ }^{21}$ ibid 470

${ }^{22} R v$ McNee [2007] EWCA Crim 1529; [2008] 1 Cr App R (S) 24

${ }^{23}$ ibid [H1]
} 


\section{Volume 1 Issue 1 Student Journal of Professional Practice and Academic Research}

years and 30 years respectively." ${ }^{24}$ In their appeal, the appellants stated, accepting it is the maximum penalty, their imposition of a discretionary life sentence was wrong in principle. It is important to note that as the offence was committed in August 2004 and life sentences for second list offences could only be imposed if the offence was committed after the section came into force. ${ }^{25}$ Therefore, it was submitted that s224A(1)(b) was inappropriate unless there was 'some imponderable feature which would make it impossible to forecast the future if the offender were ever were to be released.”26 Judges stated that Gunn would still "pose a serious danger to the public.” This was valid reason to protect the public in the future following Bentham’s theory to "punish evil."27

Furthermore, "McNee had never been convicted of any offence of violence in his past...(but)... He still was a vital member of the conspiracy, fully in the know, and giving essential help right up to the very point of the shooting." 28 In this case, there would be "uncertainty, unpredictability, instability" 29 of the future if a discretionary life sentence was not imposed. The appellants clearly committed a grave offence; therefore, it was accepted to impose the sentence as there was a greater need to protect the public.

\section{Public Protection and Sentencing}

It is common knowledge that a dangerous person's imprisonment is partly for the protection of the public. In the UK, since the abolition of capital punishment, incapacitation of dangerous offenders - especially those with an extremely low chance of rehabilitation - has been utilised to contain offenders and therefore reduce crime. However, the Carter Report 2003, attributed only a 5\% decrease in crime between 1997 and 2003 to higher custodial rates. ${ }^{30}$ This suggests that although it is important to protect society from dangerous criminals, incapacitation alone

\footnotetext{
24 ibid [H3]

${ }^{25}$ Criminal Justice Act 2003 S 224A(1)(b)

${ }^{26} \mathrm{McNee}$, (n 22) [H4]

${ }^{27}$ Bentham, (n 18)

${ }^{28}$ ibid [20]

29 ibid [25]

${ }^{30}$ Susan Easton and Christine Piper, Sentencing and punishment: the quest for justice, vol 3 (Oxford University Press 2012) 137
} 


\section{Volume 1 Issue 1 Student Journal of Professional Practice and Academic Research}

is not enough to prevent crime. The law attempts to use punishment as a deterrent to prevent others from committing crime however it clearly does not deter as many as it should.

Protection of the public is a major aim of punishment in regard to conspiracy, especially conspiracy to murder. The agreement to commit a crime suggests punishment would be used to prevent the crime agreed upon from occurring. It is necessary to point out that unlike murder, the mens rea for conspiracy to murder must include an intention to murder - not malice aforethought. This provides an explanation as to why there is such strict sentencing for conspiracy to murder as it is to punish the guilty mind not just a guilty act.

Barot $^{31}$ brought sentencing into the spotlight regarding conspiracy to murder offences. He planned a range of terror attacks on both the UK and USA, His intent was to re-enact 9/11 which was a terrorist attack which resulted in 2,996 lives lost which "horrified and angered the nation." 32 Terrorism is arguably one of the gravest crimes in the UK and it is a crime that the public need protecting from the most. Reforming the law on conspiracy to murder is imperative to prevent terrorist attacks.

Initially, Barot was sentenced to life imprisonment, with a recommendation to serve at least 40 years. However, was lowered to a minimum of 30 years in 2007. Lord Phillips said Barot's plans did not amount to an actual attempt, and it was not clear if these plans would succeed. ${ }^{33}$ This decision may have been fair on Barot's behalf but could outrage the public. Due to the court not understanding societies need to be protected from such crimes. This is where there is a struggle to balance the rights of the defendant against protection of the public - an aspect which must be strongly considered when reforming the law on conspiracy to murder.

\section{Co-conspirators and Sentencing}

\footnotetext{
${ }^{31} R$ v Dihren Barot [2007] EWCA Crim 1119

${ }^{32}$ Charles Lane, 'We Expected The War On Terror To Unite Us. What Went Wrong?' (Washington Post, 2018)

$<$ https://www.washingtonpost.com/opinions/we-expected-the-war-on-terror-to-unite-us-what-wentwrong/2018/09/10/5fb58c38-b4ff-11e8-a7b5adaaa5b2a57f_story.html?noredirect=on\&utm_term=.5fba7de06623> accessed 23 November 2018.

33 'Dirty bomb man's sentence cut' <http://news.bbc.co.uk/1/hi/uk/6661371.stm> accessed $17^{\text {th }}$ November 2018
} 


\section{Volume 1 Issue 1 Student Journal of Professional Practice and Academic Research}

When a conspiracy case involves more than one conspirator, it can be unfair that they all receive the same sentence when ultimately there is always one more guilty than another. This can be seen in Khalil ${ }^{34}$. Co-conspirators are given strict sentences to act as a deterrent to others and to protect the public from organised crimes like in Barot. ${ }^{35}$ The case of Wyllie and Bolland $^{36}$ gives an example of co-conspirators being sentenced unfairly. Although Wyllie received a longer sentence than Bolland; Wyllie was the main instigator and targeted Bolland to help him with his plot as he seemed vulnerable. Bolland still received 10 years imprisonment even though he was not the main party. Nevertheless, the court decided that it was important for both boys to receive a large sentence as their plot was so evil that they needed punishing and rehabilitating as they posed a threat to society.

Their case reflected on the 1999 Columbine school massacre where two boys of similar age killed thirteen staff and teachers and intended to kill more. It was clear to the court that the way in which the boys "hero worshipped" 37 this case made them dangerous and the plot needed to be prevented. Arnheim criticises the sentence as "unduly harsh" suggesting that the lack of access to firearms or explosives to carry out the plan meant arguably there was no conspiracy. But, in the eyes of the jury "it was a real plot" ${ }^{38}$ and they fully intended to carry the plan out. This can seem harsh, however unlike American law, the English law does not require an overt act for there to be a conspiracy.

Wyllie and Bolland can also be compared to the largely publicised case of Venables and Thompson ${ }^{39}$ where two 10 year old boys brutally murdered a 2 year old. The defendants were murderers yet had to serve the same 10 year sentence as Wyllie and Bolland. Although this is not an exact comparison as Venables and Thompson were younger, it still shows how harsh the sentencing is against conspiracy to murder for youths. It is clear from this case and many

\footnotetext{
${ }^{34}$ See page 10 lines 8-21

See also $R v$ Khalil and Others [2003] EWCA Crim 3467

${ }^{35}$ See page 7 lines 7-26

See also R v Dihren Barot [2007] EWCA Crim 1119

${ }^{36}$ Judiciary of England and Wales, Sentencing remarks of Mrs Justice Cheema-Grubb DBE (2018)

<https://www.judiciary.uk/wp-content/uploads/2018/07/r-v-wylie-and-bolland-sentencing.pdf> accessed 15 November 2018

37 ibid para 1

38 ibid para 5

39 'House Of Lords - Reg. V. Secretary Of State For The Home Department, Ex Parte V. And Reg. V. Secretary Of State For The Home Department, Ex Parte T.' (Publications.parliament.uk, 2018)

<https://publications.parliament.uk/pa/ld199798/ldjudgmt/jd970612/vandt01.htm> accessed 23 November 2018.
} 


\section{Volume 1 Issue 1 Student Journal of Professional Practice and Academic Research}

others that the law on conspiracy to murder especially on sentencing for conspiracy to murder, needs reform.

\section{Recommendations and Reforms}

The Law Commission produced a report of recommendations on Conspiracy and Attempts ${ }^{40}$, in 2009. A consultation paper ${ }^{41}$ was published on the $10^{\text {th }}$ October 2007 and a Draft Bill was published on the $10^{\text {th }}$ of December 2009. The recommendations were triggered by a House of Lords decision in the case of criminal $^{42}$ where the defendant could not be guilty of conspiracy as he only suspected the activity was criminal and the mens rea for conspiracy specifically requires intent to commit an offence. The injustice of this case made it clear the law on conspiracy was unfair and needed reform. Subsequently, the Law Commission reviewed and concluded the law to be defective. The consultation papers produced by the Law Commission outline that conspiracy to murder can be charged, whether the murder was successful or if the defendant had not yet attempted or successfully committed the murder.

Some of the recommendations made consisted of clarification to the law in relation to the agreement between co-conspirators to conspire to an offence and commit the offence conspired upon. The term "agreement" has only been defined in common law and in reforming the law, it would be useful to provide an interpretation of the word "agreement”. Jarvis suggests that an agreement is where "the parties share the same design or purpose so it can be said they truly breathe together." ${ }^{43}$ This includes the accepted interpretation established in Mehta ${ }^{44}$ and is a suggestion of the interpretation that should be included in reform.

The law currently states that spouses will not be liable for conspiracy ${ }^{45}$. The exemption for spouses is said, by the Law Commission, to be an embarrassment to a civilised system of law and therefore, should be abolished as it is an anomaly that they were exempt in the first place ${ }^{46}$ :

\footnotetext{
${ }^{40}$ Law Commission, Conspiracy and Attempts (Law Com No 318, 2007)

${ }^{41}$ Law Commission, Conspiracy and Attempts (Law Com No 183, 2009)

${ }^{42} R$ v Saik (Abdulrahman) [2007] 2 WLR 993

${ }^{43}$ Paul Jarvis and Michael Bisgrove, 'The Use And Abuse Of Conspiracy' (2014) 4 Criminal Law Review

44 See page 3 line 16

See also $R$ v Mehta (Subhash) [2012] EWCA Crim 2824

${ }^{45}$ Criminal Law Act 1977, s 2(2)

${ }^{46}$ Law Commission, Conspiracy and Attempts, (Consultation Paper No 183, 2007) Paras 1.42-1.44
} 


\section{Volume 1 Issue 1 Student Journal of Professional Practice and Academic Research}

spouses can commit conspiracy the same as anyone else. It also means that if a couple are engaged but not married, they are liable which would clearly lead to an injustice as the nature of the relationship between spouses is the same as between betrothed couples. Therefore, exemption for spouses should be abolished in reforming the law.

Currently, a co-conspirator will not be guilty of conspiracy if the other co-conspirator is the intended victim ${ }^{47}$, the Law Commission's recommendation is that the co-conspirator only should still be liable ${ }^{48}$. This is a necessary reform to keep fairness in the law; one of the aims of the law of conspiracy is to punish the guilty mind. Therefore, in a case where a coconspirator is an intended victim, the mental element is no different than any other conspiracy. Therefore, should still be convicted in the same manner as well as providing protection for the victim.

Also, recommending adding a defence of crime prevention to be consistent with other inchoate offences. ${ }^{49}$ This would mean that if a conspirator acted for the purpose of preventing crime or limit the occurrence of harm, they would have a full defence to conspiracy. This would be an effective recommendation especially in cases with undercover police officers, for example, who may conspire but in order to prevent crime from taking place.

Arnheim suggests that the law on conspiracy to murder allows too many convictions as the term "agreement” is interpreted to widely and recommends that like American law, conspiracy

should require an "overt act" to consolidate the agreement to conspire. ${ }^{50}$ This would simplify the law on conspiracy as it adds a clear actus reus element to the offence. However, this would make it harder to convict conspiracy offences and therefore contradicts the aim to have strict law on conspiracy to deter people from committing the offence. Also, adding this element would require an interpretation of what an "overt act” is, which would then complicate the law which it had intended to simplify.

\footnotetext{
47 ibid

${ }^{48}$ Law Commission, Conspiracy and Attempts (Consultation Paper No 183, 2007) paras 1.49-1.50

49 Serious Crime Act 2007, s 50

${ }^{50}$ Dr Michael Arnheim, 'A conspiracy too far?’ (2018) 168 The New Law Journal
} 


\section{Conclusion}

Without question, it is evident that the current law on conspiracy to murder is not precise and in desperate need of reform. The current statutory law on conspiracy is too broad which has led to confusion and injustice. The fact that conspiracy to murder can be given the same sentence to murder is evidently harsh and unfair, however this may have been the aim of Parliament in order to deter those from conspiring to commit murder. In order to reform the law, there must be a counter-balance between the rights of the defendant and protecting society. Recommendations provided should be considered to make the law more effective and fair. Expanding the offence so that it must include an "overt act" would be fairer on the defendant as they would only be prosecuted if they had made an active act to conspire. There are also recommendations to abolish exemptions which would broaden who could be convicted. This would allow for more convictions and therefore allow better protection for society. In conclusion, the current law on conspiracy to commit murder is not always effective and fair which means reform is required. 
Volume 1 Issue 1 Student Journal of Professional Practice and Academic Research

\section{Bibliography}

Cases

$R v$ Daddow [1996] 2 Cr App R (S) 10

$R v$ Dihren Barot [2007] EWCA Crim 1119

$R v$ Khalil and Others [2003] EWCA Crim 3467

$R v$ McNee [2007] EWCA Crim 1529; [2008] 1 Cr App R (S) 24

$R v$ Mehta (Subhash) [2012] EWCA Crim 2824

$R v$ Raw (1983) 5 Cr App R (S) 229

$R v$ Saik (Abdulrahman) [2007] 2 WLR 993

\section{Statutes}

Criminal Justice Act 2003

Criminal Law Act 1977

Offences Against the Person Act 1861

Serious Crime Act 2007 
Volume 1 Issue 1 Student Journal of Professional Practice and Academic Research

\section{Books}

Coke E, Institutes of the Laws of England 1797

Easton S and Piper C, Sentencing and punishment: the quest for justice, vol 3 (Oxford University Press, 2012) p 137

Kavanagh A and Oberdiek J, 'Arguing About Law' (Taylor and Francis 2013)

Martin J and Storey T, Unlocking Criminal Law, chapter 6.3

\section{Journal articles}

Stephen JF, A History of the Criminal Law of England, 2 228-229

Arnheim M, 'A conspiracy too far?’ (2018) 168 The New Law Journal

Jarvis P and Bisgrove M, 'The Use And Abuse Of Conspiracy' (2014) 4 Criminal Law Review

Snyman CR, 'The History And Rationale Of Criminal Conspiracy' (1984) 17 The Comparative and International Law Journal of Southern Africa

\section{Law Commission Reports}

Law Commission, 'Conspiracy And Attempts | Law Commission' (Lawcom.gov.uk, 2018)

Law Commission, Conspiracy and Attempts (Law Com No 318, 2007)

Law Commission, Conspiracy and Attempts (Law Com No 183, 2009) 
Volume 1 Issue 1 Student Journal of Professional Practice and Academic Research

\section{Websites}

--'Dirty bomb man’s sentence cut' <http://news.bbc.co.uk/1/hi/uk/6661371.stm> Accessed $17^{\text {th }}$ November 2018

--(Judiciary.uk, 2018) <https://www.judiciary.uk/wp-content/uploads/2018/07/r-v-wylie-andbolland-sentencing.pdf > accessed 15 November 2018

Lane C, 'We Expected The War On Terror To Unite Us. What Went Wrong?' (Washington Post, 2018) <https://www.washingtonpost.com/opinions/we-expected-the-war-on-terror-tounite-us-what-went-wrong/2018/09/10/5fb58c38-b4ff-11e8-a7b5-

--'House Of Lords - Reg. V. Secretary Of State For The Home Department, Ex Parte V. And Reg. V. Secretary Of State For The Home Department, Ex Parte T.'

(Publications.parliament.uk, 2018)

$<$ https://publications.parliament.uk/pa/ld199798/ldjudgmt/jd970612/vandt01.htm> accessed 23 November 2018 